\title{
Barriers to the involvement of the elderly in public services to promote physical activity
}

Renato Mendonça Ribeiro ${ }^{1}$

Sheilla Tribess ${ }^{2}$

Andrêza Soares dos Santos ${ }^{2}$

Lélia Lessa Teixeira Pinto ${ }^{2}$

Maria da Conceição Lopes Ribeiro ${ }^{2}$

Liliane Beatriz Roza ${ }^{1}$

Jair Sindra Virtuoso Júnior ${ }^{1}$

\footnotetext{
${ }^{1}$ Programa de PósGraduação em Atenção à Saúde, Universidade Federal do Triângulo Mineiro (UFTM). R. Frei Paulino 30, NS Abadia. 38025-180 Uberaba MG Brasil.jair@ ef.uftm.edu.br

${ }^{2}$ Programa de PósGraduação em Educação Física, UFTM.
}

\begin{abstract}
The aim of this study was to examine the sociodemographic, health and behavioural characteristics related to non-participation of elderly people in activities offered by the program PROETI Health of Uberaba, Minas Gerais state. Observational study, case-control design with pairing 1:1 and sample composed of 220 elderly 60-80 years. Binary Logistic Regression was used to identify the sociodemographic, health and behavioral factors associated with non-engagement of non-users to the program. After hierarchical analysis, the non-engagement of the elderly in the program activities was associated with depressive symptoms, insufficient physical activity in the domain of leisure and reduced self-efficacy for performing moderate or vigorous physical activity. The characteristics identified in this study should receive priority attention in the formulation of community programs targeted at promoting physical activity for elderly people.
\end{abstract}

Key words Motor activity, Health promotion, Health services for the elderly 


\section{Introduction}

The second half of the twentieth century was marked by a series of political, economic, technological, demographic, and social transformations. The development of new technologies and procedures in the medical sciences that were evidenced in this period, coupled with improvements in living conditions, sanitation, and maternal and child care, contributed to reducing the number of premature deaths, which triggered accelerated population aging ${ }^{1}$.

Between 2000 and 2010, the number of elderly individuals increased from 13.9 million to 19.3 million, which represents a significant increase compared with the population aged 15 to 59 years, which rose from 106.4 to 124.5 million, and the number of individuals aged 0 to 14 years, which decreased from 51 to 49.4 million $^{2}$.

The prevalence of morbidities more common in a young population and the control of parasitic and infectious diseases led to an increased prevalence of chronic degenerative diseases that are characteristic of an older population ${ }^{3}$.

Changes in the population's lifestyle due to the advent of new technologies, such as automobiles, television, and the internet, replaced the traditional activities of daily life with other activities associated with reduced energy expenditure ${ }^{1}$.

The decrease in physical activity, increased consumption of foods rich in sugar and fat, and substances harmful to health, such as alcohol and tobacco, evidenced in this period are risk factors related to the development and worsening of chronic diseases, such as obesity, diabetes, and circulatory system diseases ${ }^{4}$. These diseases had a profound impact on the economic, social, and environmental organization of Brazil and gave rise to the need for the implementation of programs aimed at the practice of physical activity ${ }^{5}$.

Starting in 2005, to meet the guidelines of the World Health Organization (WHO) and other global movements, the Brazilian Ministry of Health $(\mathrm{MOH})$ promoted projects that offered practice of physical activity, guidelines for healthy eating, preventive measures against the use of tobacco, alcohol and other drugs, prevention of traffic accidents and violence, and promotion of a culture of peace and sustainable development ${ }^{5,6}$.

These actions were established as axes of the National Policy for Health Promotion (Políti- ca Nacional de Promoção de Saúde-PNPS), adopted in 2006, which was aimed at reducing vulnerability to health risks, promoting social equity, and improving the quality of life of the population ${ }^{5}$.

The PNPS was created to understand the environmental and socioeconomic factors related to the development of chronic non-communicable diseases (CNCDs) and, through intersectoral actions, to promote the expansion of basic health services to divulge, offer, and evaluate services and programs for population-level health promotion, including the promotion of physical activity ${ }^{1}$.

Following the trends of national mobilization for health promotion initiatives, the Full Time Education Program (Programa de Educação em Tempo Integral-Proeti) of the education department of the city of Uberaba, Minas Gerais state, implemented the Proeti Health Program in 2005. The partnership among the departments of Education, Sport and Recreation, and Health, accompanied by Family Health Teams (FHT) and professionals from the Center for Support to Family Health (Núcleo de Apoio a Saúde da Família-NASF), was made official in 2008.

The Proeti Health Program centers are located in public spaces such as squares, parks, and multisport gymnasiums near FHT units and offer aerobic endurance, muscle strengthening, and balance activities in two 45-minute weekly sessions.

Despite the consensus opinion in the population regarding the benefits of physical activity to health ${ }^{7,8}$, inactivity levels remain high, requiring effort from various sectors of society for the population to adopt an active lifestyle 9 .

Despite the success enjoyed by the Proeti Health Program during its approximately onedecade-long existence, the program could be expanded with the increased participation of older people in 18 program centers distributed across the municipality. Understanding the characteristics of elderly residents in neighborhoods near centers who are not participating in the program would be useful to improve community programs aimed at promoting the practice of physical activity.

The purpose of this study was to analyze the socio-demographic, health, and behavioral characteristics related to non-participation of the elderly in the activities offered by the Proeti Health Program in Uberaba, Minas Gerais. 


\section{Methods}

The results of the present study are part of the Proeti Health Program Evaluation Study conducted in the municipality of Uberaba, Minas Gerais, in 2013. It is a case-control observational study, with 1:1 pairing (gender, age, and neighborhood) using exploratory surveys.

The sample consisted of 220 elderly women aged 60-80 years, selected by convenience. Of these, 110 were users of the Proeti Health Program (case group), and 110 were non-users (control group).

The study participants had no eyesight or hearing difficulties nor had severe cognitive disturbances. The interviewer performed the evaluation subjectively, considering the elderly individual's answers and his or her difficulty understanding the questions.

The study participants selected for the case group had been participating in the Proeti Health Program for at least 12 months. The participants selected for the control group were non-participants of the Proeti Health Program. The study participants were paired according to place of residence (neighborhood) and age group (60-64, 65-69, 70-74, or 75-80 years old).

A multidimensional interview was prepared and applied individually during the evaluation. The questionnaire was composed of questions related to socio-demographic characteristics such as age, education level, marital status, employment status, family arrangement, and economic classification, following previous study guidelines ${ }^{10}$. It also contained questions related to health indicators: perception of health ${ }^{11}$, $\operatorname{cog}$ nitive decline assessed by the Mini Mental State Examination $^{12}$, depressive symptoms assessed by the Geriatric Depression Scale ${ }^{13}$, functional capacity assessed by the rating scales of basic (BADL) and instrumental (IADL) activities of daily living ${ }^{14,15}$, behavioral aspects (including alcohol and tobacco consumption), self-esteem ${ }^{16}$, self-efficacy ${ }^{17}$, and physical activity level assessed by the International Physical Activity Questionnaire $^{18}$. Elderly women who practiced $150 \mathrm{~min}$ utes or more of moderate physical activity per week were considered active ${ }^{19}$.

The software Epidata, version 3.1b, was used to build the database, and the statistical package SPSS 15.0 (Statistical Package for the Social Sciences) was used for data analysis.

Descriptive (frequency, mean, standard deviation, and confidence interval) and inferential (Kolmogorov-Smirnov data normality test) sta- tistics were performed during data analysis. The distributions of the socio-demographic, behavioral, and health variables among groups were assessed using chi-square or Fisher's exact tests. The crude and multivariate analyses of the socio-demographic, health, and behavioral factors associated with the disengagement of non-users of the Proeti Health Program were assessed using binary logistic regression.

The variables for which the $\mathrm{p}$ values obtained in the crude analysis were $p<0.20$ (Wald test), were candidates for multiple (hierarchical) models. In block 1 were the socio-demographic conditions; in block 2 , reported health problems; and in block 3, behavioral variables. A significance level of $\mathrm{p} \leq 0.05$ and confidence interval (CI) of 95\% were adopted for the inferential analyses.

This study was approved by the Ethics Committee on Human Research of the Federal University of Triângulo Mineiro (Universidade Federal do Triângulo Mineiro - UFTM).

\section{Results}

The socio-demographic characteristics of the elderly in the case and control groups $(n=220)$ are shown in Table 1. In both groups, the women were predominantly aged 60 to 69 years and were married (or living with a partner).

Regarding family arrangements, there was a difference between the groups, with a higher frequency of the users of the Proeti Health Program living with their children and the non-users with grandchildren.

Regarding education levels, there was a higher concentration of the elderly in the case group having three or more years of education in comparison to the control group, in which illiterate elderly women or women with up to two years of education predominated. Regarding economic classification, there were more class $\mathrm{C}$ elderly women in both groups.

Regarding health (Table 2), the case group was characterized by women with positive health perception. Better sleep quality was found among the users of the Proeti Health Program in comparison to the non-users, with a higher concentration of the elderly consuming more than four medications daily in the control group.

Cognitive decline and depressive symptoms were found more frequently among the non-users of the program. When analyzing the variables related to functional capacity, both groups showed a predominance of independence in 
Table 1. Distribution of the socio-demographic variables of the elderly women in the case and control groups. Uberaba, Minas Gerais, Brazil.

\begin{tabular}{|c|c|c|c|c|c|}
\hline \multirow[b]{2}{*}{ Variable } & \multicolumn{2}{|c|}{ Case } & \multicolumn{2}{|c|}{ Control } & \multirow[b]{2}{*}{$\mathbf{p}^{*}$} \\
\hline & $\%$ & $\mathbf{N}$ & $\%$ & $\mathbf{N}$ & \\
\hline Age Group & & & & & 0.585 \\
\hline $60-69$ years & 71.8 & 79 & 70.9 & 78 & \\
\hline $70-79$ years & 27.3 & 30 & 29.1 & 32 & \\
\hline$\geq 80$ years & 0.9 & 1 & 0 & 0 & \\
\hline Marital Status & & & & & 0.338 \\
\hline Single & 9.1 & 10 & 10 & 11 & \\
\hline Married/living with a partner & 50 & 55 & 40 & 44 & \\
\hline Widowed & 28.2 & 31 & 39.1 & 43 & \\
\hline Divorced or separated & 12.7 & 14 & 10.9 & 12 & \\
\hline People in the same residence & & & & & 0.04 \\
\hline Lives alone & 17.3 & 19 & 19.1 & 21 & \\
\hline Spouse only & 25.5 & 28 & 14.5 & 16 & \\
\hline+ children & 31.8 & 35 & 25.5 & 28 & \\
\hline+ grandchildren & 14.5 & 16 & 30 & 33 & \\
\hline Others & 10.9 & 12 & 10.9 & 12 & \\
\hline Educational level & & & & & 0.018 \\
\hline Illiterate & 6.4 & 7 & 10 & 11 & \\
\hline $1-2$ years & 14.5 & 16 & 28.2 & 31 & \\
\hline$\geq 3$ years & 79.1 & 87 & 61.8 & 68 & \\
\hline Socioeconomic Level & & & & & 0.01 \\
\hline Classes A and B & 25.5 & 28 & 10 & 11 & \\
\hline Class C & 46.4 & 51 & 53.6 & 59 & \\
\hline Classes D and E & 28.2 & 31 & 36.4 & 40 & \\
\hline
\end{tabular}

"Chi-square test.

Table 2. Distribution of the health variables of the elderly women in the case and control groups. Uberaba, Minas Gerais, Brazil.

\begin{tabular}{|c|c|c|c|c|c|}
\hline \multirow[b]{2}{*}{ Variables } & \multicolumn{2}{|c|}{ Case } & \multicolumn{2}{|c|}{ Control } & \multirow[b]{2}{*}{$\mathbf{p}$} \\
\hline & $\%$ & $\mathbf{N}$ & $\%$ & $\mathbf{N}$ & \\
\hline Health Perception & & & & & $0.01^{*}$ \\
\hline Positive & 50.9 & 56 & 30 & 33 & \\
\hline Negative & 49.1 & 54 & 70 & 77 & \\
\hline Sleep quality (sleeps well) & & & & & $0.05^{*}$ \\
\hline Positive & 65.5 & 72 & 53.6 & 59 & \\
\hline Negative & 34.5 & 38 & 46.4 & 51 & \\
\hline Medicines consumed & & & & & $0.024^{* *}$ \\
\hline$\leq 1$ & 27.3 & 30 & 20.9 & 23 & \\
\hline $2-4$ & 53.6 & 59 & 43.6 & 48 & \\
\hline$>4$ & 19.1 & 21 & 35.5 & 39 & \\
\hline \multicolumn{6}{|l|}{ Cognitive decline } \\
\hline Absence & 75.5 & 83 & 62.7 & 69 & $0.029^{*}$ \\
\hline Presence & 24.5 & 27 & 37.3 & 41 & \\
\hline Depressive symptoms & & & & & $0.000^{*}$ \\
\hline Absence & 85.5 & 94 & 57.3 & 63 & \\
\hline Presence & 14.5 & 16 & 42.7 & 47 & \\
\hline BADL & & & & & $0.116^{*}$ \\
\hline Independent & 90 & 99 & 83.6 & 92 & \\
\hline Dependent & 10 & 11 & 16.4 & 18 & \\
\hline IADL & & & & & $0.002^{*}$ \\
\hline Independent & 89.1 & 98 & 72.7 & 80 & \\
\hline Dependent & 10.9 & 12 & 27.3 & 30 & \\
\hline
\end{tabular}

"Fisher's exact test (one-tailed); ${ }^{* *}$ Chi-square test. 
performing BADLs; however, regarding IADLs, a higher frequency of the elderly in the case group was classified as independent.

Regarding the behavioral aspects presented in Table 3, there were no differences between the groups for the variables related to tobacco and alcohol consumption. Self-esteem and self-efficacy for performing moderate or vigorous physical activity predominated in the case group relative to the non-users.

Table 4 lists the results of crude and hierarchical multivariate analyses, with the respective odds ratios (ORs) in the univariate analyses and adjusted for the association between independent variables and the disengagement of the elderly from the practice of physical activity.

In the crude analysis, the non-engagement of the elderly in the program's activities was associated with socioeconomic status, negative perception of health, presence of labyrinthitis, sleep quality, the number of medications consumed daily, cognitive decline, depressive symptoms, dependence in the performance of IADLs, low self-esteem, insufficient physical activity during leisure, and low self-efficacy for both walking and the performance of vigorous physical activity.

The variables measuring depressive symptoms, insufficient physical activity during leisure, and reduced self-efficacy for performing moderate or vigorous physical activity remained asso- ciated with non-adherence to the program when the adjusted analysis was performed.

\section{Discussion}

The socio-demographic and health characteristics of the study participants were similar to those reported in other studies that analyzed the profile of users of public health services ${ }^{20,21}$. The similarities in these characteristics facilitate generalization of the results and a better understanding of the needs of the individuals seeking such services.

The regular practice of physical activity promotes a positive perception of health ${ }^{11}$, improved functional capacity ${ }^{7}$, the absence of cognitive decline $^{22}$, a lower occurrence of depressive symptoms $^{23}$, high self-esteem ${ }^{16}$, better sleep quality ${ }^{24}$, and greater self-efficacy for vigorous physical activity $^{8}$.

Regarding the socio-demographic characteristics of the present study, a considerable part of both groups (case/control) lived in a multigenerational environment, an observation that is different from the reality of the elderly in other locations ${ }^{25,26}$.

The participants in the Proeti Health Program had a higher educational level than those in the control group. The practice of physical activi-

Table 3. Distribution of the behavioral variables of the elderly women in the case and control groups. Uberaba, Minas Gerais, Brazil.

\begin{tabular}{|c|c|c|c|c|c|}
\hline \multirow[b]{2}{*}{ Variables } & \multicolumn{2}{|c|}{ Case } & \multicolumn{2}{|c|}{ Control } & \multirow[b]{2}{*}{$\mathbf{p}^{*}$} \\
\hline & $\%$ & $\mathbf{N}$ & $\%$ & $\mathbf{N}$ & \\
\hline Smoker & & & & & 0.412 \\
\hline No & 71.8 & 79 & 61.8 & 68 & \\
\hline Yes & 28.2 & 31 & 38.2 & 42 & \\
\hline Alcohol consumption & & & & & 0.484 \\
\hline No & 73.4 & 80 & 74.5 & 82 & \\
\hline Yes & 26.6 & 29 & 25.5 & 28 & \\
\hline Self-esteem & & & & & 0.003 \\
\hline High & 66.4 & 73 & 47.3 & 52 & \\
\hline Low to moderate & 33.6 & 37 & 52.7 & 58 & \\
\hline Self-efficacy (walking) & & & & & 0.000 \\
\hline High & 47.3 & 52 & 17.3 & 19 & \\
\hline Low to moderate & 52.7 & 58 & 82.7 & 91 & \\
\hline $\begin{array}{l}\text { Self-efficacy (moderate to vigorous } \\
\text { physical activity) }\end{array}$ & & & & & 0.000 \\
\hline High & 77.3 & 85 & 15.5 & 17 & \\
\hline Low to moderate & 22.7 & 25 & 84.5 & 93 & \\
\hline
\end{tabular}

* Fisher's exact test (one-tailed) 
Table 4. Factors associated with the non-engagement of the elderly in the Proeti Health Program in Uberaba, Minas Gerais, Brazil.

\begin{tabular}{|c|c|c|c|c|c|}
\hline \multirow{3}{*}{ Variables } & \multirow{3}{*}{$\begin{array}{c}\text { Prevalence } \\
\%\end{array}$} & \multicolumn{3}{|c|}{ Non-members of the Proeti Health Program } & \\
\hline & & \multicolumn{2}{|c|}{ Crude Analysis } & \multicolumn{2}{|c|}{ Multivariate Analysis $^{* *}$} \\
\hline & & OR (95\% IC) & Wald & OR (95\% CI) & $\mathbf{p}^{*}$ \\
\hline \multicolumn{6}{|l|}{ Block 1 Socio-demographic aspects } \\
\hline Socioeconomic class & & & 8.58 & & 1.35 \\
\hline $\mathrm{A}, \mathrm{B}$ & 28.2 & 1 & & 1 & \\
\hline $\mathrm{C}$ & 53.6 & $2.94[1.33-6.50]$ & & $2.03[0.61-6.76]$ & \\
\hline $\mathrm{D}, \mathrm{E}$ & 56.3 & $3.28[1.41-7.61]$ & & $1.65[0.46-5.88]$ & \\
\hline \multicolumn{6}{|l|}{$\begin{array}{l}\text { Block } 2 \text { Functional and clinical aspects } \\
\text { of health }^{*}\end{array}$} \\
\hline Health Perception & & & 9.80 & & \\
\hline Positive & 37.1 & 1 & & 1 & \\
\hline Negative & 58.8 & $2.42[1.39-4.20]$ & & & \\
\hline Labyrinthitis & & & 6.94 & & 0.60 \\
\hline No & 43 & 1 & & 1 & \\
\hline Yes & 62.7 & $2.15[1.21-3.82]$ & & $1.55[0.64-3.7]$ & \\
\hline Sleep quality (sleeps well) & & & 6.25 & & \\
\hline Always & 46.3 & 1 & & & \\
\hline Almost always & 22.3 & $0.86[0.42-1.77]$ & & & \\
\hline Sometimes & 25.5 & $1.15[0.58-2.28]$ & & & \\
\hline Never/rarely & 15 & $2.66[1.12-6.29]$ & & & \\
\hline Medications & & & 7.27 & & \\
\hline$<2$ & 43.4 & 1 & & & \\
\hline $2-4$ & 44.9 & $1.06[0.54-2.06]$ & & & \\
\hline$>4$ & 65 & $2.42[1.13-5.17]$ & & & \\
\hline Cognitive decline & & & 4.12 & & \\
\hline Absence & 45.4 & 1 & & & \\
\hline Presence & 60.3 & $1.82[1.02-3.26]$ & & & \\
\hline Depressive symptoms & & & 19.8 & & 7.28 \\
\hline Absence & 40.1 & 1 & & 1 & \\
\hline Presence & 74.6 & $4.38[2.28-8.40]$ & & 3.50 [1.40-8.69] & \\
\hline IADLs $^{\mathrm{a}}$ & & & 8.98 & & \\
\hline Independent & 44.9 & 1 & & & \\
\hline Dependent & 71.4 & $3.06[1.47-6.36]$ & & & \\
\hline \multicolumn{6}{|l|}{ Block 3 Behavioral Aspects ${ }^{* *}$} \\
\hline Self-esteem & & & 8.05 & & \\
\hline Positive & 41.6 & 1 & & & \\
\hline Negative & 61.1 & $2.20[1.27-3.79]$ & & & \\
\hline Physical activity during leisure time & & & 53.88 & & 31.48 \\
\hline$\geq 150 \mathrm{~min} /$ week & 16.3 & 1 & & 1 & \\
\hline$<150 \mathrm{~min} /$ week & 71.6 & $12.9[6.55-25.7]$ & & $12.8-[5.26-31.3]$ & \\
\hline Self-efficacy (walking) & & & 21.21 & & \\
\hline Positive & 26.8 & 1 & & & \\
\hline Negative & 61.1 & $4.3[2.31-7.98]$ & & & \\
\hline $\begin{array}{l}\text { Self-efficacy (moderate/vigorous } \\
\text { physical activity) }\end{array}$ & & & 70.42 & & 41.61 \\
\hline High & 16.7 & 1 & & 1 & \\
\hline Low & 78.8 & $18.6[9.39-36.8]$ & & $15.5[6.76-35.8]$ & \\
\hline
\end{tabular}

\footnotetext{
(a) Instrumental activities of daily living; ${ }^{*}$ Controlled by socio-demographic aspects and functional and clinical health aspects; ${ }^{* *}$ Controlled by socioeconomic class, labyrinthitis, depressive symptoms, physical activity during leisure and self-efficacy for moderate or vigorous physical activity.
} 
ty, especially during leisure, may be related to the number of years of education due to its relationship with income and access to information related to the benefit of physical activity to health, or even to the structure of leisure activities ${ }^{27}$.

Concerning socioeconomic aspects, both groups showed a predominance of the elderly belonging to economic class C. However, some of the users of the Proeti Health Program also belong to the upper levels of economic classification (classes A and B), a characteristic that differentiates it from the control group, which was represented by the lower classification strata, namely classes $\mathrm{D}$ and $\mathrm{E}$.

The greater adherence of the elderly in better financial situations to the practice of physical activity is corroborated by a study conducted in Brazill $^{28}$. However, this finding does not reflect a consensus in the literature: some studies have reported an inverse relationship between income and higher levels of physical activity in regions with lower economic power ${ }^{26,29}$, with the difference marked by time spent by the elderly in domestic activities ${ }^{26}$.

Regarding perceptions of health, the users of the Proeti Health Program reported more optimism than the non-users. These data corroborate the results of other studies that have compared the perceptions of health held by the elderly who were exposed versus not exposed to the practice of physical activity ${ }^{11,30}$.

Among the users of the program, the high percentage of elderly individuals who reported negative health perceptions may be related to the search for the program by people who have a health condition because the FHT refers elderly individuals with CNCDs to the Proeti Health Program. The routing of sick individuals to services promoting physical activity is a trend observed in other programs and reflects the heritage of the curative model, focused on symptoms, which can contribute to reducing the effectiveness of the intervention $^{31}$.

Regarding sleep quality, the elderly in the case group reported a positive perception more frequently in comparison with the elderly in the control group; these results are corroborated by the literature ${ }^{32}$. Among the possible explanations for this relationship is the fact that sleep disorders are related to diminished physical disposition and deterioration in physical and psychological indicators of one's quality of life ${ }^{24}$.

Regarding the consumption of medications, more than $1 / 3$ of the non-users of the Proeti Health Program consumed more than 4 medi- cations per day, a percentage considerably higher than that among the users. Other studies have also identified an inverse relationship between regular physical activity and the consumption of medications $^{31,33}$.

The consumption of some medications, in addition to being a marker of a clinical health condition, can produce side effects, such as dizziness, which in turn is associated with a higher prevalence of falls, and this may be the reason for the non-users' failure to join physical activity programs $^{34}$.

Cognitive decline is considered a serious public health problem in many countries, being related to an increased risk of developing dementia, functional disability, and negative health habits, including physical inactivity ${ }^{35,36}$.

Mild cognitive decline was identified in more than $1 / 3$ of the elderly in the control group, which was higher than the prevalence in the case group. This inverse relationship between physical activity and the presence of mild cognitive decline has frequently been reported in the literature $22,37,38$. The limitations inherent in exploring the cognitive variable in population studies should be emphasized, due to the impossibility of obtaining reliable data through questionnaires applied to individuals with mild cognitive impairment.

Depression is recognized as an extremely costly disease in several countries and is reported in the literature as the fourth leading cause of premature disability, being related to changes in mood, sadness, and discouragement ${ }^{23,39}$.

Regarding depressive symptoms, the program's non-users showed a high prevalence of such symptoms in relation to users, results similar to those found in national surveys ${ }^{39,40}$. The inverse relationship between physical activity and the presence of depressive symptoms may be explained by the fact that the behavioral variable has psychosocial dimensions that favor communication and decreased social isolation ${ }^{40}$.

The prevalence of dependence in the performance of BADLs was similar in both groups, whereas the prevalence of dependence in the performance of IADLs was higher in the control group than in the case group.

The functional disability of the control group in performing BADLs was similar to what has been reported in surveys conducted in other regions of the country but with lower prevalence compared with IADLs ${ }^{10,41}$. The elderly participants in the case group exhibited a lower prevalence of disability in BADLs and IADLs than in studies conducted in the country ${ }^{10,41}$. Regular 
physical activity helps maintain and/or develop fitness and psychosocial features, which in turn act positively on the functional performance of the elderly ${ }^{42}$.

Regarding behavioral attributes, high perceived self-esteem of the elderly in the case group was higher than that of the control group. These results corroborate evidence found in another study, which compared self-esteem in active and inactive elderly individuals ${ }^{16}$. An increased level of physical activity is associated with better self-esteem, which in turn is related to lower levels of depressive symptoms ${ }^{16}$.

Low levels of self-efficacy for walking were observed in both groups. However, among the program's users, $47.3 \%$ reported having high self-efficacy for performing this activity, a higher rate than the one reported among the non-users $(17.3 \%)$. The differential self-efficacy for performing moderate or vigorous physical activity observed between the two groups was more pronounced, with a high level of self-efficacy for performing these activities among the elderly in the case group and a lower level among the elderly in the control group.

High self-efficacy is related to the performance and maintenance of healthy habits, as well as participation in social activities, whereas low levels of self-efficacy are related to elderly individuals' decreased perceptions of their ability to cope with changes and perform new activities ${ }^{43}$. Evidence has shown that high self-efficacy encourages the elderly to search for habits that promote health benefits ${ }^{44}$.

Regarding the factors associated with the non-engagement of elderly women in the activities offered by the Proeti Health Program, in the adjusted analysis, their non-engagement in the program was significantly associated with depressive symptoms, insufficient physical activity during leisure time and reduced self-efficacy for performing moderate or vigorous physical activity.

Some socio-demographic characteristics are determinants of an active lifestyle, and it was identified in the crude analysis that membership of the elderly in the $\mathrm{C}, \mathrm{D}$, and $\mathrm{E}$ economic classes was more common in the control group; however, this association did not remain in the adjusted analysis. Some studies have identified an inverse relationship between socioeconomic status and the engagement of older people in the practice of physical activity ${ }^{26,29}$.

Socio-economic status is related to education and health care and support ${ }^{26}$; however, this variable may have been suppressed in the analy- sis due to the strength of interaction exhibited by behavioral variables.

Among the diseases reported, labyrinthitis, despite not having remained in the adjusted analysis, was associated with the non-engagement of the elderly in the crude analysis, being a common disease during aging that is related to dizziness and loss of balance and that contributes to the occurrence of falls, which in turn generate inconveniences for elderly individuals ${ }^{34}$.

Depressive symptoms were associated with non-participation in the activities offered by the Proeti Health Program in the control group, even when controlled by other variables. This relationship is understandable because the disease is associated with psychological distress, the loss of appetite, and the neglect of self-care ${ }^{23,39}$.

Because it is a complex disease, depression represents an obstacle to health services, which should be organized to detect its symptomatology and adequately attend to its presentation in the elderly, who are more susceptible to this condition $^{39}$. The high prevalence of depressive symptoms among elderly women in the control group and the inverse relationship between physical activity and the prevalence of depression found in the literature ${ }^{22,28}$ indicate the development of specific actions to encourage the adhesion of non-users to the Proeti Health Program.

An insufficient level of physical activity during leisure time was also associated with the non-adherence of the elderly in the control group to the activities offered by the Proeti Health Program. The practice of physical activity as leisure is necessary for individuals of all ages and especially for the elderly because they are more susceptible to low levels of activity in general, particularly with regard to work, due to retirement-a factor also related to diminished social interaction ${ }^{45}$.

Evidence in the literature demonstrates that low economic class, low educational attainment, the presence of mental disorders, such as depression, functional losses resulting from the aging process and a lack of adequate public spaces are closely related to physical inactivity in leisure time $^{27,45}$. Such evidence corroborates some findings of this study with regard to determining the factors predicting non-engagement in the program.

Low self-efficacy for moderate and vigorous physical activity was identified in the present study as a predictive factor for non-adherence to the Proeti Health Program by the elderly in the control group. When self-efficacy-understood to mean the willingness, interest, and determina- 
tion that the individual has to acquire new habits - is high, it emerges as one of the factors related to the adoption of healthy lifestyles, including physical activity ${ }^{46}$.

In this context, it is understandable that low self-efficacy to perform moderate and vigorous activities is related to the non-adherence of the elderly women in the control group to the Proeti Health Program. It is necessary to devise strategies to identify the willingness for behavioral change that exists among the non-users of the program toward the objective of implementing motivational and encouragement strategies for the development of self-efficacy and, consequently, adherence to the program ${ }^{47}$.

Several limitations to this study can be noted: 1) the questionnaire used may underestimate or overestimate some of the findings; 2) the non-mandatory nature of regular attendance at the program and the lack of a formal record of attendance hinder the analysis of performance indicators, as well as the development of each specific unit, because some elderly individuals perform physical activities in different units during the week.

In contrast, the possibility of bias in sample selection is reduced due to the method of pairing by gender, age group, and neighborhood, which facilitated the comparison of users and non-users with similar characteristics, thus reducing the influence of possible confounding factors on the results.

\section{Conclusion}

The data analyzed in this study indicated that symptoms, a low level of physical activity during leisure time, and reduced self-efficacy for moderate and/or vigorous physical activity are predictive factors for the non-engagement of elderly women in the control group to the Proeti Health Program even when controlling for socio-demographic and clinical health attributes.

\section{Contributors}

RM Ribeiro and JS Virtuoso Junior conceived and designed the study, analyzed and interpreted the data, wrote and critically reviewed the manuscript, and approved the version to be published. S Tribess, AS Santos, LLT Pinto, MCL Ribeiro, LB Roza participated in the writing and critical review of the manuscript and approved the version to be published

\section{Acknowledgements}

We are grateful to the Coordination for Training of Higher Education Personnel (Coordenação de Aperfeiçoamento de Pessoal de Nível SuperiorCAPES) for granting the Master's scholarship and the Municipal Department of Sports and Recreation of Uberaba for authorizing the study. 


\section{References}

1. Costa FF, Garcia LMT, Nahas MVA. A Educação Física no Brasil em Transição: perspectivas para a promoção de atividade física. Rev Bras Ativ Fís Saúde 2012; 17 (1):14-21.

2. Instituto Brasileiro de Geografia e Estatística. Sintese de indicadores sociais: uma análise das condições de vida da população brasileira. Rio de Janeiro, 2010.

3. Carmo EH, Silva Junior JB, Barreto ML. Mudanças nos padrões de morbimortalidade da população brasileira: os desafios para um novo século. Epidemiol Serv Saude 2003; 12(2):63-75.

4. Van der Ploeg HP, Chey T, Korda RJ, Banks E, Bauman A. Sitting Time and All-Cause Mortality Risk in 222497 Australian Adults. Arch Intern Med 2012; 172(6):494-500.

5. Malta DC, Castro AM, Gosch CS, Cruz DKA, Bressan A, Nogueira JD, Morais Neto OL, Temporão JG. National policy of health promotion and the motor activity agenda in the context of the National Health System in Brazil. Epidemiol Serv Saúde 2009; 18(1):79-86.

6. Knuth AG, Malta DC, Cruz DK, Freitas PC, Lopes MP, Fagundes J, Reis RS, Hallal PC. Rede Nacional de Atividade Física do Ministério de Saúde: resultados e estratégias avaliativas. Rev Bras Ativ Fís Saúde 2010; 15(4):229-233.

7. Mullen SP, McAuley E, Satariano WA, Kealey M, Prohaska TR. Physical Activity and Functional Limitations in Older Adults: The Influence of Self-Efficacy and Functional Performance. J Gerontol B Psychol Sci Soc Sci 2012; 67(3):354-361.

8. Xue QL, Bandeen-Roche K, Mielenz TJ, Seplaki CL, Szanton SL, Thorpe RJ, Kalyani RR, Chaves PH, Dam TT, Ornstein K, RoyChoudhury A, Varadhan R, Yao W, Fried LP. Patterns of 12-Year Change in Physical Activity Levels in Community-Dwelling Older Women: Can Modest Levels of Physical Activity Help Older Women Live Longer? Am J Epidemiol 2012; 176(6):534-543.

9. Sousa CA, César CL, Barros MB, Carandina L, Godbaum M, Marchioni DM, Fisberg RM. Prevalence of leisure-time physical activity and associated factors: a population-based study in São Paulo, Brazil, 20082009. Cad Saude Publica 2013; 29(2):270-282.

10. Virtuoso Júnior JS, Guerra RO. Factors associated to functional limitations in elderly of low income. Rev Assoc Med Bras 2008; 54(5):430-435.

11. Benedetti TRB, Mazo GZ, Borges LJ. Condições de saúde e nível de atividade física em idosos participantes e não participantes dos grupos de convivência de Florianópolis. Cien Saude Colet 2012; 17(8):2087-2093.

12. Almeida OP. Mini exame do estado mental e o diagnóstico de demência no Brasil. Arq Neuropsiquiatr 1998; 56(3):605-612.

13. Almeida OP, Almeida AS. Confiabilidade da versão brasileira da escala de depressão em geriatria (GDS) versão reduzida. Arq Neuropsiquiatr 1999; 57(3):421-426.
14. Lino VTS, Pereira SRM, Camacho LAB, Ribeiro Filho ST, Buksman S. Adaptação transcultural da Escala de Independência em Atividades da Vida Diária (Escala de Katz). Cad Saude Publica 2008; 24(1):103-112.

15. Lopes RS, Virtuoso Júnior JS. Confiabilidade da versão brasileira da escala de atividades instrumentais da vida diária. RBPS 2008; 21(4):290-296.

16. Meurer ST, Borges LJ, Benedetti TRB. Associação entre sintomas depressivos, motivação e autoestima de idosos praticantes de exercícios físicos. Rev Bras Ciênc Esporte 2012; 34(3):683-695.

17. Rech CR, Sarabia TT, Fermino RC, Hallal PC, Reis RS. Psychometric properties of a self-efficacy scale for physical activity in Brazilian adults. Rev Panam Salud Publica 2011; 29(4):259-266.

18. Benedetti TRB, Mazo GZ, Barros MVG. Aplicação do questionário internacional de atividades físicas (IPAQ) para avaliação do nível de atividades físicas de mulheres idosas: validade concorrente e reprodutibilidade teste-reteste. R Bras Ci e Mov 2004; 12(1):25-34.

19. Haskell WL, Lee IM, Pate RR, Powell KE, Blair SN, Franklin BA, Macera CA, Heath GW, Thompson PD, Bauman A. Physical activity and public health: updated recommendation for adults from the American College of Sports Medicine and the American Heart Association. Circulation. 2007;116(9):1081-1093.

20. Victor JF, Ximenes LB, Almeida PC, Vasconcelos FF. Perfil sociodemográficos e clínico de idosos atendidos em Unidade Básica de Saúde da Família. Acta Paul Enferm 2009; 22(1):49-54.

21. Virtuoso JF, Mazo GZ, Menezes EC, Cardoso AS, Dias RG, Balbé GP. Perfil de morbidade referida e padrão de acesso a serviços de saúde por idosos praticantes de atividade física. Cien Saude Colet 2012; 17(1):23-31.

22. Benedetti TRB, Borges LJ, Petroski EL, Gonçalves LHT. Atividade física e estado de saúde mental de idosos. Rev Saude Publica 2008; 42(2):302-307.

23. Lucas M, Mekary R, Pan A, Mirzaei F, O’Reilly EJ, Willett WC, Koenen K, Okereke OI, Ascherio A. Relation between clinical depression risk and physical activity and time spent watching television in older women. a 10-year prospective follow up study. Am J Epidemiol 2011; 174(9):1017-1027.

24. Mello MT, Boscolo RA, Esteves AM, Tufik S. Physical exercise and the psychobiological aspects. Rev Bras Med Esporte 2005; 11(3):203-207.

25. Pavarini SCI, Luchesi BM, Fernandes HCL, Mendiondo MSZ, Filizola CLA, Barham EJ, Oishi J. Genograma: avaliando a estrutura familiar de idosos de uma unidade de saúde da família. Rev Eletr Enf 2008; 10(1):39-50.

26. Tribess S, Virtuoso Junior JS, Petroski EL. Atividade física e aspectos sociodemográficos de mulheres idosas. RBSP 2009; 33(3):336-348. 
27. Pitanga FJ, Lessa I. Prevalência e fatores associados ao sedentarismo no lazer em adultos. Cad Saude Publica 2005; 21(3):870-877.

28. Reichert FF, Barros AJ, Domingues MR, Hallal PC. The role of perceived personal barriers to engagement in leisure-time physical activity. Am J Public Health 2007; 97(3):515-519.

29. Batista NNLAL, Vieira DJN, da Silva GMP. Caracterização de idosos participantes de atividade física em um centro de convivência de Teresina-PI. Enferm Foco 2012; 3(1):7-11.

30. Vita A, Neri AL, Padovani CR. Saúde percebida em homens e mulheres sedentários e ativos, adultos, jovens e idosos. Salusvita 2006; 25(1):23-34.

31. Costa BVL, Mendonça RD, Santos LC, Peixoto SV, Alves M, Lopes ACS. Academia da Cidade: um serviço de promoção de saúde na rede assistencial do Sistema Único de Saúde. Cien Saude Colet 2013; 18(1):95-102.

32. Ribeiro JAB, Cavalli AS, Cavalli MO, Pogorzelskil LV, Prestes MR, Ricardo LIC. Adesão de idosos a programas de atividade física: motivação e significância. Rev Bras Ciênc Esporte 2012; 34(4):969-984.

33. Silva LJ, Azevedo MR, Matsudo S, Lopes GS. Associação entre nível de atividade física e o uso de medicamentos em mulheres idosas. Cad Saude Publica 2012; 28(3):463-471.

34. Miranda RV, Mota VP, Borges M. Quedas em idosos: identificando fatores de risco e meios de prevenção. Rev Enf Int 2010; 3(1): 453-464.

35. Geda YE, Silber TC, Roberts RO, Knopman DS, Christianson TJ, Pankratz VS, Boeve BF, Tangalos EG, Petersen RC. Computer Activities, Physical Exercise, Aging and Mild Cognitive Impairment: A population based study. Mayo Clin Proc 2012; 87(5):437-442.

36. Nagamatsu LS, Handy TC, Hsu CL, Voss M, Liu-Ambrose $\mathrm{T}$. Resistance training promotes cognitive and functional brain plasticity in seniors with probable mild cognitive impairment: A 6-month randomized controlled Trial. Arch Intern Med 2012; 172(8):666-671.

37. Garber CE, Greaney ML, Riebe D, Nigg CR, Burbank PA, Clark PG. Physical and mental health-related correlates of physical function in community dwelling older adults: a cross sectional study. BMC Geriatr 2010; 10:6.

38. Wang HX, Jin Y, Hendrie HC, Liang C, Yang L, Cheng Y, Unverzagt FW, Ma F, Hall KS, Murrell JR, Li P, Bian J, Pei JJ, Gao S. Late life leisure activities and risk of cognitive decline. J Gerontol A Biol Sci Med Sci 2012; 68(2):205-213.

39. Siqueira GR, Vasconcelos DT, Duarte GC, Arruda IC, Costa JA, Cardoso RO. Análise da sintomatologia depressiva nos moradores do Abrigo Cristo Redentor através da aplicação da Escala de Depressão Geriátrica (EDG). Cien Saude Colet 2009; 14(1):253-259.
40. Reichert CL, Diogo CL, Vieira JL, Dalacorte RR. Physical activity and depressive symptoms in community dwelling elders from southern Brazil. Rev Bras Psiquiatr 2011; 33(2):165-170.

41. Del Duca GF, Silva MC, Hallal PC. Disability relating to basic and instrumental activities of daily living among elderly subjects. Rev Saude Publica 2009; 43(5):796805.

42. Ueno DT, Gobbi S, Teixeira CVL, Sebastião E, Prado AKG, Costa JL, Gobbi LTB. Efeito de três modalidades de atividade física na capacidade funcional de idosos. Rev Bras Educ Fís Esporte 2012; 26(2):273-281.

43. Rabelo DF, Cardoso CM. Autoeficácia, doenças crônicas e incapacidade funcional na velhice. PsicoUSF 2007; 12(1):75-81.

44. Silva MCS, Lautert L. O senso de autoeficácia na manutenção de comportamentos promotores de saúde de idosos. Rev Esc Enferm USP 2010; 44(1):61-67.

45. Zaitune MP, Barros MB, César CL, Carandina L, Goldbaum M. Variables associated with sedentary leisure time in the elderly in Campinas, São Paulo State, Brazil. Cad Saude Publica 2007; 23(6):1329-1338.

46. McAuley E, Mullen SP, Szabo AN, White SM, Wójcicki TR, Mailey EL, Gothe NP, Olson EA, Voss M, Erickson K, Prakash R, Kramer AF. Self-Regulatory Process and Exercise Adherence in Older Adults: Executive Functions And Self Efficacy Effects. Am J Prev Med 2011; 41(3):284-290.

47. De Oliveira JG, Barbosa JPAS, Farah BQ, Chehuen MR, Cucato GG, Wolosker N, Forjaz CLM, Dias RMR. Estágios de mudança de comportamento e fatores associados à prática de atividade física em indivíduos com claudicação intermitente. Einstein 2012; 10(4):422-427.

Article submitted on 10/04/2014

Approved on 03/09/2014

Final versoin submitted on 05/09/2014 
